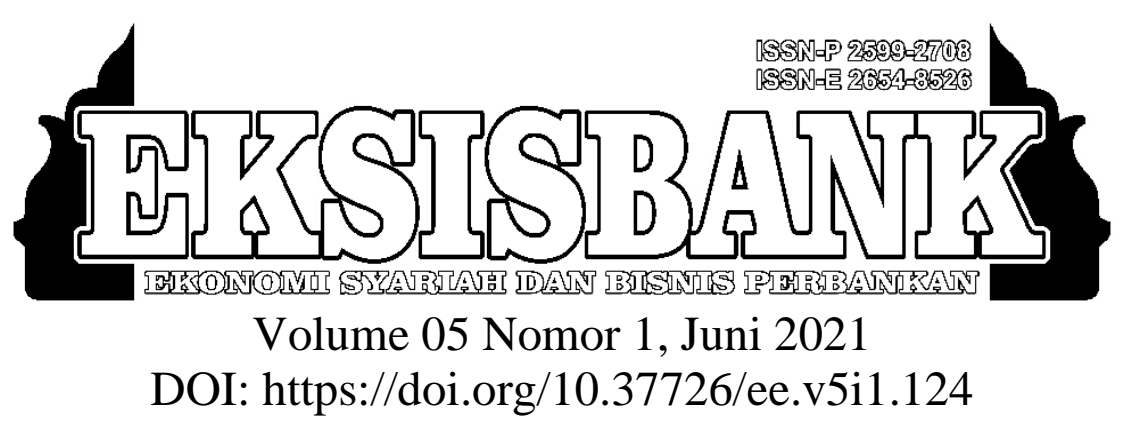

\title{
Analisis Jual Beli Golok Dengan Cara Panjar Dalam Perspektif Ekonomi Syariah Di PG. Binangkit Kp. Cibeureum Tanjungsiang Subang
}

\author{
Abdul Hopid ${ }^{1}$, Jalaludin ${ }^{2}$, Ahmad Damiri ${ }^{3}$ \\ ${ }^{1}$ Sekolah Tinggi Agama Islam (STAI) Riyadhul Jannah Subang \\ ${ }^{2,3}$ Sekolah Tinggi Ilmu Ekonomi Syariah (STIES) Indonesia Purwakarta \\ 1abdulhopid48@gmail.com \\ 2jalaludinstiesip@gmail.com \\ 33ahmaddamiri@sties-purwakarta.ac.id
}

\begin{abstract}
ABSTRAK
Dalam Islam bermuamalah adalah salah satu bentuk kemudahan bagi manusia untuk memenuhi segala sesuatu yang berhubungan dengan kebutuhan hidupnya sehari-hari sebagai mahluk hidup maupun mahluk sosial, diantara tindakan masyarakat untuk memenuhi kebutuhan materi ialah jual beli dengan sistem panjar, namun beberapa masyarakat masih belum memahami tentang praktek jual beli dengan sistem panjar dalam perspektif ekonomi syariah. Penelitian ini bertujuan untuk mengetahui jual beli sistem panjar menurut para ahli, dan untuk mengetahui tinjauan ekonomi syariah terhadap jual beli golok cara panjar di PG. Binangkit Cibeureum Tanjungsiang Subang. Penelitian ini merupakan jenis penelitian kualitatif dengan pendekatan empiris, teknik pengumpulan data yang digunakan adalah obsevasi, wawancara, dokumentasi. Dalam penelitian ini sumber data terdiri dari data primer yakni pengelola dan pemilik PG. Binangkit Kp. Cibeureum Tanjungsiang-Subang dan data sekunder berupa catatan atau arsip yang ada di PG. Binangkit. Mengenai jaul beli dengan sistem panjar fikih As-Syafi'i berpendapat tidak sah, berdasarkan hadis yang diriwayatkan oleh Amru bin Syuaib yang berbunyi, "dari amru bin Syu'aib dari ayahnya dan kakeknya meridhoi Allah akanya bahwa Nabi bersabda: Nabi saw melarang jual-beli "urban (HR Abu Daud)". Pemahaman fiqh As-Syafi'i ini untuk menghidari dari isi kandungan surah an-Nisa ayat 29. Yang berbunyi. "Hai orang-orang yang beriman, janganlah kamu saling memakan harta sesamamu dengan jalan yang batil, kecuali dengan jalan perniagaan yang Berlaku dengan suka sama-suka di antara kamu. dan janganlah kamu membunuh dirimu Sesungguhnya Allah adalah Maha Penyayang kepadamu" Sedangkan Pemahaman fikih Hanbali tentang jual beli uang muka berpendapat bahwa jual beli tersebut adalah sah. Berdasarkan Hadis yang diriwayatkan oleh Zaid bin Aslam dan Atsar sahabat atau praktek sahabat Nabi saw, yaitu Umar yang
\end{abstract}

EKSISBANK (Ekonomi Syariah dan Bisnis Perbankan), Volume 5, Nomor 1, Juni 2021 http://journal.sties-purwakarta.ac.id/index.php/EKSISBANK/ 
membeli bangunan penjara kepada Safwan bin Ummayyah. "Rasulullah Saw ditanya tentang jual-beli sistem 'urbun, dan beliau membolehkannya." Pendapat yang berhubungan erat di PG. Binangkit Cibeureum Tanjungsiang tentang pelaksanaan jual beli golok dengan system uang panjar adalah pendapat fikih Hanbali dimana praktek tersebut melakukan jual beli golok dengan memakai uang panjar karena jual beli yang terjadi di PG. Binangkit Cibeureum Tanjungsiang adalah boleh karena hal tersebut untuk memastikan keberlangsungan transaksi dan jaga-jaga atas jual beli golok. Selanjutnya tinjauan ekonomi syariah berdasarkan hasil analisis peneliti maka transaksi jual beli golok baik dengan sistem panjar dan langsung di PG. Binangkit sudah sesuai dengan syariah baik dari ketentuan terkait sighat al-aqd, para pihak yang berakad, Mutsman/mabi' (Objek), dan ketentuan terkait Tsaman atau harganya.

Kata kunci-Jual Beli Golok, Beli Golok Sistem Panjar, Sistem Panjar dalam Perspektif Ekonomi Syariah.

\section{ABSTRACT}

In Islam, muamalah is a form of convenience for humans to fulfill everything related to their daily needs as living beings and social beings, among the actions of the community to meet material needs is buying and selling with a down payment system, but some people still do not understand about the practice of buying and selling with a down payment system in a sharia economic perspective. This study aims to determine the sale and purchase of the down payment system according to the experts, and to find out the sharia economic review of buying and selling machetes in PG. Binangkit Cibeureum Tanjungsiang Subang. This research is a type of qualitative research with an empirical approach, the data collection techniques used are observation, interviews, and documentation. In this study, the data sources consist of primary data, namely PG managers and owners. Binangkit Kp. Cibeureum Tanjungsiang-Subang and secondary data in the form of records or archives in PG. Raise. Regarding jaul-buying using the Jurisprudence system, As-Syafi'i is of the opinion that it is invalid, based on the hadith narrated by Amru bin Shuaib which reads, "From Amru bin Shu'aib, his father and grandfather were pleased with Allah, so the Prophet said: The Prophet forbade selling- buy 'urban' (Narrated by Abu Dawud)". The understanding of As-Shafi'i fiqh is to avoid the contents of the content of Surah an-Nisa verse 29. Which reads. "O you who believe, do not eat each other's property in a vanity way, except by means of commerce, which prevails consensual among you. and do not kill yourself. Indeed, Allah is Most Merciful to you." While the Hanbali fiqh understanding of the sale and purchase of advances is of the opinion that the sale and purchase is valid. Based on the Hadith narrated by Zaid bin Aslam and Atsar companions or the practice of the Prophet's companions, namely Umar who bought the prison building to Safwan bin Ummayyah. "The Messenger of Allah was asked about buying and selling the 'urbun system, and he allowed it." Opinions closely related in PG. Binangkit Cibeureum Tanjungsiang regarding the implementation of buying and selling machetes with a down payment system is the opinion of Hanbali fiqh where the practice of buying and selling machetes using down payment is due to the buying and selling that occurs in PG. Binangkit Cibeureum Tanjungsiang is allowed because this is to ensure the continuity of the transaction and guard against buying and selling machetes. Furthermore, a review of Islamic economics based on the results of the researcher's analysis, the sale and purchase of machetes both with the down payment system and directly in the PG. Binangkit is in accordance with sharia both from the provisions related 
to sighat al-aqd, the parties to the contract, Muthman/mabi '(Object), and the provisions related to Tsaman or the price.

Keywords - Buy and Sell Golok, Buy Golok with the Advance System, the Payment System in the Perspective of Sharia Economics.

\section{PENDAHULUAN}

Secepat perkembangan manusia, secepat itu pula manusia menghadapi perkembangan masalah yang harus dihadapinya, yang semakin hari semakin kompleks adalah masalah ekonomi. Orang memiliki banyak sekali kebutuhan, keinginan (Puspitasari, Saepudin, and Rohmat 2019), keperluan yang kesemuannya itu menghendaki pemenuhan. Dan pemenuhannya itu tidak lain adalah barang dan jasa. Untuk memecahkan masalahmasalah ekonomi yang dihadapi sehari-hari, manusia haruslah bertindak harus berbuat dengan tujuan memecahkan masalah-masalah ekonomi baik untuk mencukupi kebutuhan pribadinya (Suherman 2006).

Quraish Shihab menyatakan aktivitas antar manusia termasuk aktivitas ekonomi terjadi melalui istilah muamalah (interaksi), dimana muamalah lebih mengacu kepada aspek sosial ekonomi saja dalam islam (Mulyana 2009). Manusia adalah mahluk sosial yang hidup berkelompok yang senantiasa membutuhkan orang lain, oleh karena itu manusia senantiasa membutuhkan interaksi dengan manusia yang lain (Basrun 2014). Adapun yang menyebabkan manusia selalu bermasyarakat antara adanya dorongan kesatuan biologis yang terdapat dalam naluri, misalnya: 1). Hasrat untuk memenuhi keperluan makan dan minum. 2). Hasrat untuk membela diri. 3). Hasrat untuk mengadakan keturunan.

Hal ini dinyatakan semenjak manusia lahir yang dinyatakan untuk mempunyai dua keinginan pokok, yaitu: 1). Keinginan untuk menjadi satu dengan manusia sekelilingnya. 2). Keinginan untuk menjadi satu dengan suasana alam sekelilingnya.
Bermuamalah adalah salah satu bentuk kemudahan bagi manusia untuk memenuhi segala sesuatu yang berhubungan dengan kebutuhan hidupnya sehari-hari sebagai mahluk individu maupun mahluk sosial, seiring bergulirnya waktu dan berkembangnya zaman dalam hal bermuamalah di era globalisasi sekarang ini sangat beragam dengan bermacam-macam cara untuk memenuhi kebutuhan masing masing. Menurut Abdul Rahman Ghazali aturan aturan Allah SWT untuk mengatur manusia dalam hidup dan kehidupan terdapat pada muamalah (Ghazaly, Ihsan, and Shidiq 2010).

Setiap orang mempunyai perbedaan kemampuan karena fitrah manusia diciptakan dengan kelebihan dan kekurangan tersendiri. Jika mempunyai kelebihan pada suatu bidang tentu di sisi yang lain memiliki kekurangan. Untuk memenuhi kebutuhan yang tidak dimiliki adalah dengan jual beli dengan orang lain. Permasalahan yang timbul dari transaksi jual beli di masyarakat sekarang ini adalah penerapan uang panjar atau biasa disebut uang muka, DP (down of payment), atau al-urbun (A. Mas'adi 2002).

Secara mutlak panjar adalah bagian dari adat dalam bidang muamalah. Dalam kegiatan muamalah dituntut untuk senantiasa berpegang teguh pada ajaran-ajaran islam sebagai sumber etikanya yang didalamnya harus melibatkan prinsip-prinsip muamalah.

Panjar secara umum termasuk muamalat yang belum pernah disinggung didalam AlQur'an dan Hadist secara langsung, maka hukumnya dikembalikan kepada hukum asal muamalah, yaitu dibolehkan. Para ulama 
menyebutkan hal tersebut dengan mengemukakan kaidah fiqih yang berbunyi :

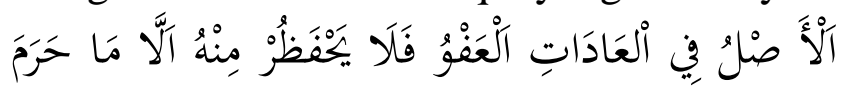

"Hukum asal dalam muamalat adalah pemanfaatan, tidak ada yang diharamkan kecuali apa yang diharamkan Allah $S W T$ "(Dzajuli 2007).

Hukum asal dalam transaksi muamalah adalah halal. Semua transaksi yang tidak ada dalil syariat yang mengharamkannya diperbolehkan. panjar berisi unsur kerjasama, tolong-menolong dalam kebaikan dan taqwa, karena ia adalah salah satu cara memenuhi kebutuhan orang yang butuh dan menolong mereka untuk menjauhi muamalat terlarang. Sebagai sarana tolong menolong antara sesama umat manusia mampunyai landasan yang kuat dalam Al-Qur'an. Dalam hal ini, Allah SWT berfirman, Q.S Al-Maidah ayat 2:

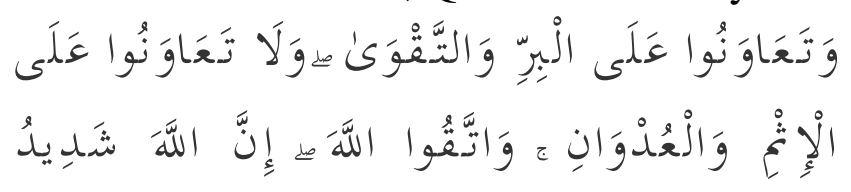
الْعَعَاب الْعَ

"Dan tolong-menolonglah kamu dalam (mengerjakan) kebajikan dan takwa, dan jangan tolong-menolong dalam berbuat dosa dan pelanggaran. Dan bertakwalah kamu kepada Allah, sesungguhnya Allah amat berat siksa-Nya".(QS. Al-Maidah : 2) (Subarkah et al. 2012).

Untuk melakukan kegiatan jual-beli, Islam menghendaki agar dilakukan dengan cara yang sah. Kegiatan jual-beli hendaknya tidak dijadikan ajang bisnis yang kurang sehat, dalam arti pihak yang mengadakan transaksi tidak merasa dirugikan. Dalam hal ini, mempunyai landasan yang kuat dalam $\mathrm{Al}$ -
Qur'an dan Hadist. Dalam Firman Allah SWT Q.S Al-Baqarah:275:

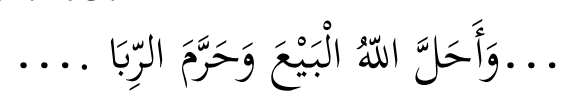

"Sesungguhnya Allah SWT telah menghalalkan jual beli dan mengharamkan riba" (Subarkah et al. 2012).

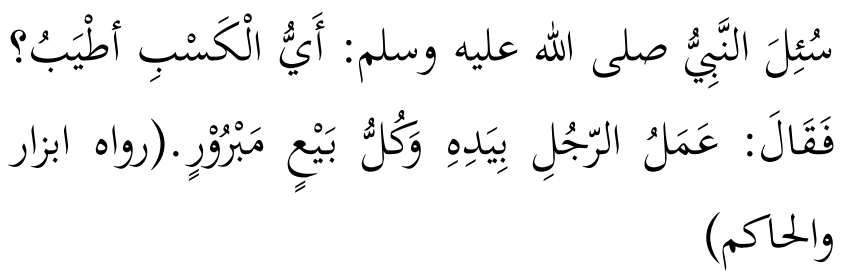

"Rasulullah SAW. Ditanya salah seorang sahabat mengenai pekerjaan (profesi) apa yang paling baik. Rasulullah saw. Menjawab: usaha tangan manusia sendiri dan setiap jual beli yang diberkati" (HR. Al-Bazzar dan AlHakim).

Berdasarkan ayat dan hadist di atas bahwa manusia dilarang memperoleh harta dengan jalan bathil yang akan merugikan orang lain. Islam mengajarkan kepada umatnya agar di dalam memperoleh harta dengan jalan yang baik dan benar serta tidak merugikan orang lain (Jamil, Kurnia, and Jalaludin 2020). Setiap umat Islam boleh mencari nafkah dengan cara jual beli, tetapi cara harus dilakukan sesuai dengan syariat Islam, tidak boleh merugikan orang lain, tidak saling menipu orang lain, kepentingan umum dan bebas memilih sehingga tidak ada unsur memaksa (Labib 2006).

Dari beberapa teori diatas dapat di pahami bahwa inti Jual beli adalah suatu perjanjian tukar menukar benda atau barang yang mempunyai nilai secara sukarela di antara kedua belah pihak, yang satu menerima benda-benda dan pihak lain menerima sesuai dengan perjanjian atau ketentuan yang telah dibenarkan syara' dan disepakati. Pada dasarnya jual beli adalah memindahkan barang dari tangan penjual ke tangan pembeli

EKSISBANK (Ekonomi Syariah dan Bisnis Perbankan), Volume 5, Nomor 1, Juni 2021 
barang yang dapat dimanfaatkan oleh si pembeli di dasarkan atas saling rela.

Sebuah fenomena yang cukup menarik, berhasil penyusun temui dari pengamatan terhadap kegiatan jual beli golok dengan cara di panjar di kampung Cibeureum. Pada kasus ini yang unik adalah keberadaan panjar dalam jual beli golok. Ada pihak yang menganut pandangan bisnis bahwa panjar merupakan perjanjian, jika terjadi pembatalan transaksi uang tersebut tidak boleh dikembalikan adalah boleh. Ada juga yang menganggap praktek tersebut memanfaatkan kesempatan dalam kesempitan sehingga merugikan salah satu pihak. Hal itu disebabkan tidak ada bukti, atau surat perjanjian pada waktu pembayaran uang panjar tentang kejelasan, tindak lanjut, ataupun aturan main yang harus ditaati oleh calon pembeli maupun penjual setelah transaksi panjar tersebut dilakukan (Rusyd 2016).

Jual beli yang dilakukan harus membawa manfaat bagi kedua belah pihak dan tidak merugikan. Aktivitas jual beli juga harus dilandasi oleh rasa suka sama suka. Apabila tidak ada persetujuan dari pihak pembeli dan orang yang menjual maka dianggap tidak sah karena bisa saja keputusan yang diambil hanya keinginan dari salah satu pihak. Penerapan uang muka bisa merugikan salah satu pihak dan mengurangi tujuan menciptakan kemaslahatan bagi sesama umat. Padahal Islam mengajarkan agar manusia saling tolong menolong dalam berbuat kebaikan dan bukan pada perbuatan yang merugikan orang lain.

Adapun rukun jual beli menurut jumhur ulama ada empat, yaitu:

1. $B a$ 'I (penjual)

2. Mustari (pembeli)

3. Shighat (ijab qobul)

4. Ma'qud alaih (benda atau barang) (Ghazaly, Ihsan, and Shidiq 2010)

Allah SWT berfirman: Al-Maidah (5): 2.

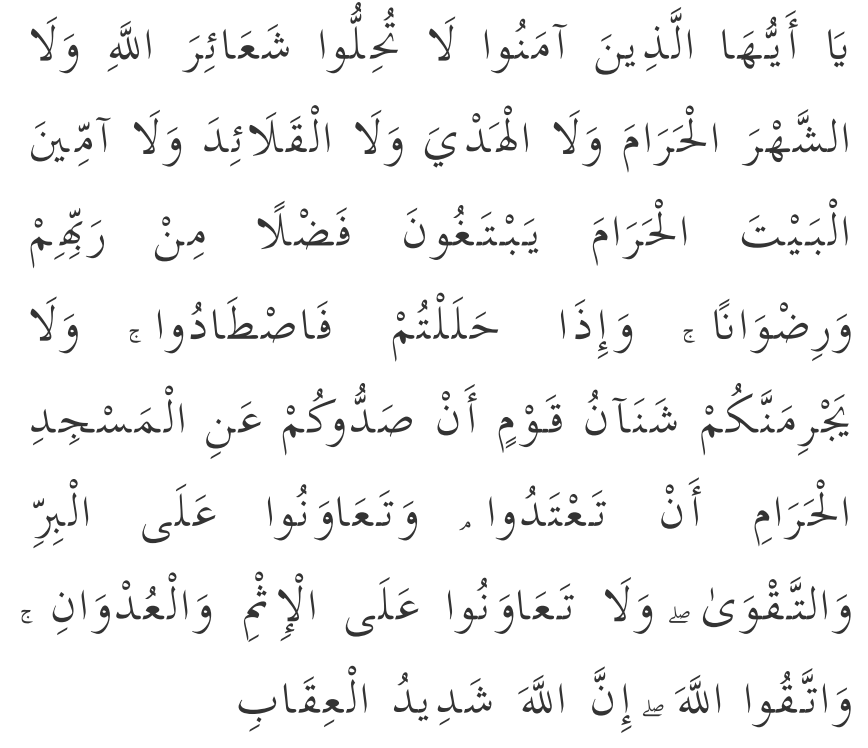

"Hai orang-orang yang beriman, janganlah kamu melanggar syi'ar-syi'ar Allah dan jangan melanggar kehormatan bulanbulan haram jangan (mengganggu) binatangbinatang had-ya dan binatang-binatang qalaa-id dan jangan (pula) mengganggu orang-orang yang mengunjungi Baitullah sedang mereka mencari kurnia dan keredhaan dari Tuhannya dan apabila kamu telah menyelesaikan ibadah haji, Maka bolehlah berburu. dan janganlah sekali-kali kebencian(mu) kepada sesuatu kaum karena mereka menghalang-halangi kamu dari Masjidilharam, mendorongmu berbuat aniaya (kepada mereka). dan tolong-menolonglah kamu dalam (mengerjakan) kebajikan dan takwa, dan jangan tolongmenolong dalam berbuat dosa dan pelanggaran. dan bertakwalah kamu kepada Allah, Sesungguhnya Allah Amat berat siksaNya)"

Keputusan memang berada di tangan pembeli, karena dari awal sudah tahu ada peraturan bahwa uang muka tidak akan dikembalikan, walaupun jadi atau batal dalam jual beli. Tergantung perjanjian awal antara kedua pihak apabila terjadi pembatalan uang panjar tersebut akan dikembalikan atau tidak. Jika sejak awal sudah ada ketentuan bahwa

EKSISBANK (Ekonomi Syariah dan Bisnis Perbankan), Volume 5, Nomor 1, Juni 2021 
tidak dikembalikan, maka pihak yang batal membeli tidak boleh menuntut karena sudah menyetujui akad yang telah ditentukan semula. Pengelola tidak bisa disalahkan jika uang muka tidak dikembalikan, sebab perjanjian terdahulu telah disetujui bersama.

Berdasarkan kegelisahan terhadap permasalahan panjar tersebut, maka penyusun sangat tertarik untuk meneliti pandangan hukum Islam terhadap penerapan panjar dalam jual beli golok di Cibeureum, Desa Tanjungsiang Kecamatan Tanjungsiang.

Adapun tujuan penelitian ini adalah untuk mengetahui jual beli sistem panjar menurut para ahli, dan untuk mengetahui tinjauan ekonomi syariah terhadap jual beli golok cara panjar di PG. Binangkit Cibeureum Tanjungsiang Subang.

\section{TINJAUAN PUSTAKA}

Penelitian tentang Analisis Jual Beli Golok Dengan Cara Panjar Dalam Perspektif Ekonomi Syariah sudah banyak dilakukan oelh peneliti sebelumnya, seperti penelitianpenelitian yang dilakukan oleh peneliti sebagai berikut:

A. Pelaksanaan Jual Beli Kredit Peralatan

Rumah Tangga Ditinjau dari Kompilasi

Hukum Ekonomi Syariah (Studi Kasus di

Desa Huristak, Kec. Huristak Kab. Padang

Lawas) (Harahap 2017)

Masalah yang dibahas dalam penelitian ialah bagaimanakah pelaksanaan jual beli kredit peralatan rumah tangga yang ada di desa Huristak Kecamatan Huristak Kabupaten Padang Lawas, dana bagaimana bila ditinjau dari Kompilasi Hukum Ekonomi Syari'ah. Penelitian ini adalah penelitian lapangan. Metode yang digunakan adalah deskriptif yaitu berusaha untuk menggambarkan dan menginterpretasikan fenomena sesuai dengan apa adanya. Sumber data ada dua yaitu primer dan skunder, sementara instrument pengumpulan data yaitu wawancara, observasi dan dokumentasi.

Penelitian ini menemukan bahwa pelaksanaan jual beli kredit peralatan rumah tangga yang ada di desa Huristak Kecamatan Huristak Kabupaten Padang Lawas sebagian sangat antusias, menerima dan terbuka jual beli secara kredit. proses yang ditawarkan juga sangat mudah serta barang yang ditawarkan sesuai dengan keinginan ibu-ibu yang ada di desa Huristak. Apabila terjadi keterlambatan dalam pembayaran, biasanya kreditur akan memberikan tenggang waktu. Jual beli kredit peralatan rumah tangga ditinjau dari Kompilasi Hukum Ekonomi Syari'ah (KHES) di desa Huristak Kecamatan Huristak Kabupaten Padang Lawas bertentangan dengan Kompilasi Hukum Ekonomi Syari'ah (KHES). Sebab, dalam Kompilasi Hukum Ekonomi Syari'ah (KHES) dijelaskan dalam bagian ketujuh pasal 116 yaitu penjual harus membeli barang yang diperlukan pembeli atas nama penjual sendiri, dan pembelian ini harus bebas riba, dan penjual harus memberi tahu secara jujur tentang harga pokok barang kepada pembeli berikut biaya yang diperlukan.

Perbedaan peneliti terdahulu dengan penelitian saat ini adalah peneliti terdahulu mengkaji atau menganalisis pelaksanaan Jual Beli Kredit pada Peralatan Rumah Tangga Ditinjau dari Kompilasi Hukum Ekonomi Syariah. Sedangkan pada penelitiaan saat ini peneliti mengkaji atau menganalisis tinjauan ekonomi Syariah terhadap jual beli golok dengan cara panjar. perbedaan selanjutnya dari segi lokasi dan objek penelitian yang berbeda pula. Peneliti terdahulu melakukan penelitian di Desa Huristak, Kec. Huristak Kab. Padang Lawas, sedangkan penelitian saat ini dilakukan di PG. Binangkit Cibeureum Tanjungsiang Subang. Selanjutnya terkait objek penelitian, peneliti terdahulu mengkaji system jual beli kredit, 
sedangkan peneliti saat ini mengkaji jual beli system panjar atau uang muka. Persamaannya kedua penelitian tersebut sama-sama mengkaji atau meneliti jual beli tidak tunai.

\section{B. Tinjauan Ekonomi Islam Pada Prospek Industri Daur Ulang Sampah Plastik (Musyahidah et al. 2020)}

Tulisan ini membahas permasalahan perekonomian masyarakat dan permasalah sampah yang semakin mengganggu di kota Palu. Metode yang digunakan dalam penelitian ini adalah: metode pendekatan kualitatif deskriftif yang berisi gambaran tentang latar pengamatan, orang, tindakan, dan pembicaraan. Adapun sumber datanya adalah informan yaitu ketua anggota dan beberapa anggota yang bekerja di industri Tondo Mandiri. Adapun analisis data yang digunakan dalam penelitian ini adalah analisis deskriftif dengan menggambarkan dan menginterprensikan data dan temuan-temuan yang peneliti peroleh dari lapangan serta fakta-fakta yang ada. Hasil penelitian Tondo Mandiri tidak mempunyai prospek yang baik untuk kemajuan usaha kedepannya dikarenakan masalah dan hambatan yang dihadapinya. Kemudian ditinjau dari Ekonomi Islam Penulis memandang industri ini secara umum tidak bertentangan dengan ketentuan dalam syariat Islam, namun belum dapat sepenuhnya dikatakan sesuai dengan tinjauan Ekonomi Islam, karena ada beberapa hal yang dilakukan oleh para pekerja yang belum memenuhi syarat untuk dikatakan sesuai dengan aturan Syariat Islam.

Perbedaan peneliti terdahulu dengan penelitian saat ini adalah peneliti terdahulu mengkaji atau menganalisis Tinjauan Ekonomi Islam Pada Prospek Industri Daur Ulang Sampah Plastik. Sedangkan pada penelitiaan saat ini peneliti mengkaji atau menganalisis tinjauan ekonomi Syariah terhadap jual beli golok dengan cara panjar. perbedaan selanjutnya dari segi lokasi dan objek penelitian yang berbeda pula. Peneliti terdahulu melakukan penelitian di kota Palu, sedangkan penelitian saat ini dilakukan di PG. Binangkit Cibeureum Tanjungsiang Subang. Selanjutnya terkait objek penelitian, peneliti terdahulu mengkaji daur ulang sampah, sedangkan peneliti saat ini mengkaji jual beli system panjar atau uang muka.

\section{METODOLOGI PENELITIAN}

Sumber data dalam penelitian adalah subjek dari mana data dapat diperoleh (Arikunto 2006). Dalam penelitian ini, data yang dibutuhkan peneliti diperoleh dari dua sumber, yaitu:

\section{A. Sumber Data Primer}

Sumber data ini adalah sumber pertama di mana sebuah data dihasilkan (Bungin 2001). Dalam penelitian ini, data primer diperoleh dengan wawancara langsung yang dilakukan kepada pemilik PG. Binangkit yang berada di kampung cibeureum desa tanjungsiang kabupaten subang. Orang-orang yang membeli golok ke PG. Binangkit adalah sebagai pelaku Sehingga mereka menjadi informan penting dalam pelaksanaan jual beli. Selain itu peneliti juga mengamati langsung pada situasi dan kondisi objek yang diteliti.

\section{B. Sumber data sekunder}

Sumber data sekunder adalah sumber data kedua sesudah sumber data primer. Fungsi sumber data sekunder adalah membantu memberi keterangan atau data pelengkap sebagai bahan pembanding (Bungin 2001). Data pelengkap yang dikorelasikan dengan data primer dapat berupa informasi dari orang lain, dokumentasi, buku-buku, artikel di internet atau di media massa.

\section{Lokasi Penelitian}

Lokasi Penelitian adalah tempat yang berkaitan dengan sasaran atau permasalahan penelitian dan juga merupakan salah satu jenis sumber data yang dapat dimanfaatkan oleh 
peneliti (Utopo 2002). Pemilihan lokasi atau site selectio nmenurut Sukmadinata berkenaan dengan penentuan unit, bagian, kelompok, dan tempat dimana orang-orang terlibat di dalam kegiatan atau peristiwa yang akan diteliti (Heryanto 2021).

Penelitian ini mengambil lokasi di PG. Binangkit kampung Cibeureum Kecamatan Tanjungsiang Kabupaten Subang. Penelitian ini dilakukan di toko tersebut karena toko tersebut merupakan salah satu toko yang menjual berbagai macam perkakas seperti golok dan lain sebagainya. Memang di daerah Kecamatan Tanjungsiang terkenal dengan kerajinan tangannya seperti golok, arit, parang dan alat perkakas lainnya. Sehingga diharapkan masyarakat yang kreatif disana dapat tersalurkan bakat seni kerajinan tangannya.

\section{Waktu Penelitian}

Waktu Penelitian tentang penjualan golok dengan system panjar di PG. Binangkit Kampung Ciberem Kecamatan Tanjungsiang Kabupaten Subang diadakan selama 3 bulan, yaitu pada bulan Juli 2019 sampai bulan September 2019.

Jenis penelitian ini adalah penelitian kualitatif deskriptif, yaitu data yang dikumpulkan berbentuk kata-kata, gambar, bukan angka-angka (Ramdhani, Rodiyah, and Mardiyansyah 2020). Menurut Bog dan dan Taylor, sebagaimana yang dikutip oleh Lexy J. Moleong, penelitian kualitatif adalah prosedur penelitian yang menghasilkan data deskriptif berupa kata-kata tertulis atau lisan dari orang-orang dan perilaku yang diamati (Rahman, Sudarno, and Roziq 2018). Sementara itu, penelitian deskriptif adalah suatu bentuk penelitian yang ditujukan untuk mendeskripsikan atau menggambarkan fenomena-fenomena yang ada, baik fenomena alamiah maupun rekayasa manusia (Zaenuri 2014).
Adapun tujuan dari penelitian deskriptif adalah untuk membuat pencandraan secara sistematis, faktual, dan akurat mengenai fakta dan sifat populasi atau daerah tertentu. Penelitian ini digunakan untuk mengetahui bagaimana pelaksanaan jual beli dengan sistem panjar di PG.Binangkit kampung ciberem kecamatan Tanjungsiang Kabupaten Subang.

Pengertian teknik pengumpulan data menurut Arikunto adalah cara-cara yang dapat digunakan oleh peneliti untuk mengumpulkan data, di mana cara tersebut menunjukan pada suatu yang abstrak, tidak dapat di wujudkan dalam benda yang kasat mata, tetapi dapat dipertontonkan penggunaannya (Arikunto 2002). Dalam hal pengumpulan data ini, penulis terjun langsung pada objek penelitian untuk mendapatkan data yang valid, maka peneliti menggunakan metode sebagai berikut:

\section{E. Metode Observasi}

Observasi atau pengamatan dapat diartikan sebagai pengamatan dan pencatatan secara sistematis terhadap gejala yang tampak pada objek penelitian. Observasi ini menggunakan observasi partisipasi, di mana peneliti terlibat langsung dengan kegiatan sehari-hari orang yang sedang diamati atau yang digunakan sebagai sumber data penelitian (Sugiyono 2006). Dalam observasi secara langsung ini, peneliti selain berlaku sebagai pengamat penuh yang dapat melakukan pengamatan terhadap gejala atau proses yang terjadi didalam situasi yang sebenarnya yang langsung diamati oleh observer, juga sebagai pemeran serta atau partisipan yang ikut melaksanakan proses penjualan golok dengan system panjar di PG.Binangkit tersebut.Observasi langsung ini dilakukan peneliti untuk mengoptimalkan data mengenai pelaksanaan penjualan golok di PG.Binangkit, interaksi penjual dan pembeli dalam bertransaksi, keadaan tempat penjualan, serta proses panjar tersebut. 


\section{F. Metode Wawancara (Interview)}

Wawancara adalah percakapan dengan maksud tertentu yang dilakukan oleh dua pihak, yaitu pewawancara (interviewer) yang mengajukan pertanyaan dan yang diwawancarai (interviewee) yang memberikan jawaban atas pertanyaan (Moleong 2000). Dalam hal ini, peneliti menggunakan wawancara terstruktur, di mana seorang pewawancara menetapkan sendiri masalah dan pertanyaan-pertanyaan yang akan diajukan untuk mencari jawaban atas rumusan masalah yang telah disusun (Moleong 2000).

Dalam melaksanakan teknik wawancara (interview), pewawancara harus mampu menciptakan hubungan yang baik sehingga informan bersedia bekerja sama, dan merasa bebas berbicara dan dapat memberikan informasi yang sebenarnya. Teknik wawancara yang peneliti gunakan adalah secara terstruktur (tertulis) yaitu dengan menyusun terlebih dahulu beberapa pertanyaan yang akan disampaikan kepada informan. Hal ini dimaksudkan agar pembicaraan dalam wawancara lebih terarah dan fokus pada tujuan yang dimaksud dan menghindari pembicaraan yang terlalu melebar. Selain itu juga digunakan sebagai patokan umum dan dapat dikembangkan peneliti melalui pertanyaan yang muncul ketika kegiatan wawancara berlangsung (Arikunto 2002).

Metode wawancara peneliti gunakan untuk menggali data terkait pelaksanaan jual beli golok dengan system panjar di PG. Binangkit. Adapun informannya antara lain:

a. Staf karyawan, untuk mendapatkan informasi tentang pelaksanaan penjualan golok di PG. Binangkit.

b. Kepala Balai, untuk mendapatkan informasi tentang profil PG. Binangkit. c. Pihak-pihak lain yang berkaitan dengan perolehan data dalam penulisan skripsi ini.

\section{G. Metode Dokumentasi}

Dokumentasi, dari asal kata dokumen yang artinya barang-barang tertulis. Dalam pelaksanaan metode dokumentasi, peneliti menyelidiki benda-benda tertulis seperti buku-buku, majalah, dokumen, peraturanperaturan, notulen rapat, catatan harian dan sebagainya (Arikunto 2013). Melalui metode dokumentasi, peneliti gunakan untuk menggali data berupa dokumen terkait dengan penjualan golok di PG. Binangkit

\section{HASIL DAN PEMBAHASAN A. Ketentuan Jual Beli Cara Panjar Menurut Para Ahli}

Di zaman yang modern ini telah muncul berbagai macam praktik jual beli, diantaranya jual-beli golok dengan cara panjar (persekot) akad salam. Jual-beli ini sudah tidak asing lagi bagi masyarakat dan sudah menjadi kebiasaan disemua kalangan. Praktik jual beli golok dengan cara panjar akad salam ini dilakukan sebagaimana jual beli pada umumnya. Praktek yang tejadi di PG. Binangkit Cibeureum Tanjungsiang bahwa jual beli golok dengan cara panjar akad salam antara penjual dan pembeli. Pembeli menyerahkan sejumlah uang kepada penjual, maka uang muka ini sebagai bagian dari harga, pembeli memberikan uang kepada penjual dan mengatakan uang tersebut uang tanda jadi. Kemudian penjual memberikan jangka waktu yang telah ditentukan untuk pembayaran penuh dengan harga golok yang di sepakati dan juga membuat kesepakatan apabila pembeli membatalkan atau tidak jadi membelinya maka uang panjar menjadi milik penjual.

Pada umumnya, praktek panjar berlaku di segala penjuru, mengenai jual beli golok dengan memakai uang panjar atau uang muka, 
awal mulanya transaksi ini untuk memperjelas perjanjian dalam kesepakatan. Seorang pembeli melihat dulu barang yang ia inginkan, beberapa golok ia cek untuk memastikan golok tersebut bagus atau tidak untuk di gunakan sehari-hari. Adapun beberapa jenis perkakas yang di jual di PG. Binangkit tersebut. Seperti parang, arit, kujang, cangkul dan lain sebagainya.

Pandangan ahli fiqih dari kalangan Syafi'iyyah berpendapat jual-beli ini tidak sah. Pendapat yang dijelaskan dalam kitab alMajmu' karangan Imam Nawawi, salah satu dari pengikut Imam As-Syafi'i menjelaskan;

فرع :فن مذابب العلماء في بيع العربون قد ذكرنا ان فيو من الشرط الفاسد والغرار, و و اكل الدال بالباطل

"Para ulama mazhab tentang jual beli sitem panjar, sesunggunya telah kami sebutkan bahwa imam As-Syafi'i batalnya jual beli sistem panjar jika di syaratkan pada akad transaksi, dan bagi syaratnya termasuk jual beli yang pasid dan gharar, karena memakan harta dengan cara yang batil" (AnNawawi n.d.).

Selain itu, pernyataan dalam kitab alHasyyatan Qalyubi dan Umairah menyebutkan:

$$
\begin{aligned}
& \text { (ولايصح بيع العربون) بفتح العتُ والراء و بضم العتُ } \\
& \text { واسكان الراء (بأن يشتى ويعطيو درام لتكون من } \\
& \text { الثمن ان رضى السلعة و إلا فهبة) }
\end{aligned}
$$

"(Dan tidak sah jual beli al-'urbun) yaitu dengan memfatahkan huruf ain dan raa' atau membariskan depan/ domah huruf ain dan mensukunkan huruf raa' (dengan ketentuan, pembeli memberikan uang dirham (kepada penjual) untuk terhitung sebagai harga, jika suka terhadap barang atau jika tidak, maka menjadi hibah" (Al-Ramli n.d.).
Beberapa pernyataan pengikut Imam AsSyafi'i di atas dijelaskan bahwa dari pengharaman jual-beli ini adalah karena ia termasuk memakan harta orang lain secara batil, terdapat gharar di dalamnya, dan dua syarat yang fasad, yaitu syarat hibah dan syarat mengembalikan barang jika tidak disukai. Ia juga merupakan khiyar yang majhul, karena ia mensyaratkan pengembalian barang tanpa menyebutkan batas waktu. Mereka melandasi pendapatnya berdasarkan hadits dari 'Amr ibn Syu'aib, dari ayahnya, dari kakeknya, ia berkata

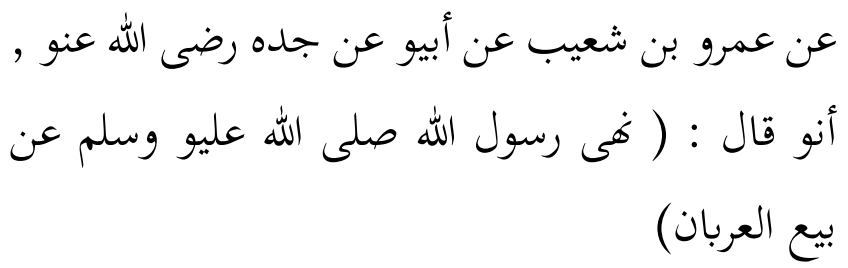

"Dari Umar bin Syu'aib dari ayahnya dan kakeknya meridhoi Allah akanya bahwa Nabi bersabda: Nabi saw melarang jual-beli 'urban' (HR Abu Daud)" (As-Syarbaini 1978).

Adapun kalangan Hanabilah berbeda pendapat dengan pendapat dari kalangan Syafi'iah. Mereka menyatakan jual-beli semacam ini boleh saja hukumnya. Sebagaimana di jelaskan dalam kitab AlMughni;

$$
\begin{aligned}
& \text { فصل: والعربون فن البيع و ان يشتَى السلعو فيدفع } \\
& \text { إبل البائع درمها أو غَته ، على انو إن أخاذالسلعة ك } \\
& \text { إحتسب بو من الثمن وإن مل يأخذ لا فذالك للباع } \\
& \text { يقال العربون ، قال أححد : ال بئس بون }
\end{aligned}
$$

"Jual beli dengan uang panjar adalah untuk membelikan sesuatu dari si penjual, maka harus dibayar kepada penjual satu dirham atau lebih, atas bahwasanya jika mengambil si penjual, menghitung denganya dari pada harga, dan jika tidak

EKSISBANK (Ekonomi Syariah dan Bisnis Perbankan), Volume 5, Nomor 1, Juni 2021 
mengambilnya bagi pembeli, maka yang demikian di sebutlah jual beli urbun dan berkata Imam Ahmad: membolehkan jual beli sistem 'Urbun." (Qudamah n.d.)

Pendapat ini juga disandarkan kepada 'Umar ibn Al-Khaththab dan putranya, radhiyallahu 'anhuma. Hanabilah juga mengajukan riwayat yang menunjukkan bolehnya jual-beli ini. 'Abdur Razzaq meriwayatkan dalam Mushannaf-nya dari Zaid ibn Aslam, ia menyatakan:

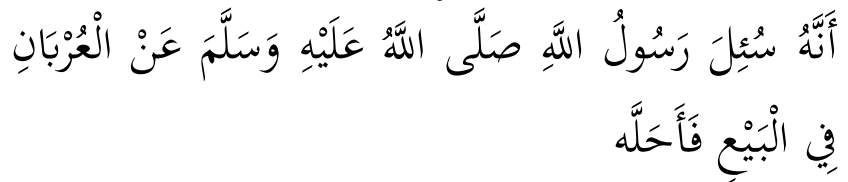

"Rasulullah Saw ditanya tentang jual-beli sistem "urban, dan beliau membolehkannya."

Penjelasan dari kedua pendapat yang bertentangan antara fiqh As Syafi'I dan fiqh Al-Hanbali bahwa pendapat yang membolehkan secara tegas di jelaskan dalam kitab pengikut Imam Al-Hanbali. Dan yang melarang jual beli di lain pendapat bahwa mereka berargumentasi jual-beli ini adalah karena ia termasuk memakan harta orang lain secara batil, terdapat gharar di dalamnya, dan dua syarat yang fasad, yaitu syarat hibah dan syarat mengembalikan barang jika tidak disukai, namun hadits yanga di riwayatkan Imam syafi'i tidak bersambung sanadnya jadi tidak di pakai sebagai hujah. Ia juga merupakan khiyar yang majhul, karena ia mensyaratkan pengembalian barang tanpa menyebutkan batas waktu.

Adapun Pegnertian Panjar Menurut Para Ahli diantaranya;

1. Menurut Hisam ad-Din al-Turfawi, 'urbun adalah (Al-Turfawi n.d.)

Pertama secara etimologis, Ibnu Mundzir berkata: arroba, wa arbana, wa huwa urban, wa 'urbun, wa 'arbun dikatakan, bahwasannya dinamai demikian karena sebagai uang panjar dalam akad jual beli.
Yaitu perbaikan dan penghilangan kerusakan supaya tidak dimiliki oleh pembeli selainnya. Kedua secara terminologi, memiliki dua makna, yaitu: Pertama: seseorang membeli barang dagangan dan menyerahkan sebagain uang kepada penjual, apabila ia jadi melakukan jual beli ia akan menyempurnakan pembayaran, apabila tidak jadi melakukan jual beli maka ia (penjual) mengembalikan apa yang ia terima.

Kedua: Seseorang membeli barang dagangan dan menyerahkan sejumlah uang kepada penjual, apabila pembeli melangsungkan transaksi jual beli maka pembeli akan membayar penuh, dan apabila pembeli tidak jadi melangsungkan jual beli, maka uang muka tersebut menjadi milik penjual dan tidak pembeli tidak meminta uang mukanya kembali. Adapaun yang dimaksud jual beli 'urbun adalah seseorang membeli sebuah barang kemudian ia membayar satu dirham atau sebagian kecil dari harga barang kepada penjual, dengan syarat apabila transaksi jual beli dilanjutkan maka satu dirham yang telah dibayarkan itu akan terhitung sebagai bagian dari harga barang, akan tetapi apabila transaksi jual beli tidak jadi, maka satu dirham yang telah dibayarkan akan menjadi pemberian (hibah) bagi penjual.

2. Menurut Sa'di Abu Jaib (Jaib 1988)

Urbun adalah seorang pembeli mendahulukan pembayaran dan akan melunasinya apabila jadi melakukan transaksi jual beli, apabila tidak jadi melakukan transkasi jual beli, maka uang yang yang didahulukan menjadi milik penjual.

3. Menurut Malikiyah, Hanafiyah, Syafi'iyah dan Hanabilan 
Urbun ialah Seseorang membeli sesuatu, atau menyewa sesuatu, dan memberikan sebagian uang atau ujroh kepada pembeli. Kemudian pembeli berkata kepada penjual: "Apabila aku jadi membeli barang tersebut, maka aku akan menyempurnakan pembayarannya, dan apabila aku tidak jadi maka itu adalah milikmu dan aku tidak akan mengambilnya kembali darimu. Menurut Mau'suah al-Fiqhiyyah al-Kuwaitiyyah urbun adalah: (Departemen Wakaf dan Persoalan Keiskalam Kuwait, 1427)

Al-'arabun dengan menggunakan dua fathah seperti halazun, wa al-urbun wizan ushfur, lughotun fih. Al-urban dengan dhommah lughatun tsalits dengan wazan (timbangan) qurban. Adapun dengan menggunakan fathah dan sukun adalah lahnun (tidak tepat membacanya) tidak ada perbincangan di dalamnya menurut orang-orang Arab. Itu adalah mu'arrab. Para ahli memberikan tafsir secara bahasa adalah apa-apa yang diakadkan dalam jual beli.

4. Menurut istilah fiqih

Adalah seorang pembeli membeli sesuatu, dan menyerahkan kepada penjual satu dirham atau lebih, apabila ia mengambil barang dagangan tersebut dari penjual, maka ia (pembeli) akan menyempurnakan pembayarannya, dan apabila pembeli tidak jadi mengambil (barang dagangan) tersebut maka uang yang telah diberikan pembeli kepada penjual akan menjadi milik penjual.

5. Menurut Hisan al-Din 'Afanah

Urbun adalah $B a$ ' $i$ al-'urbun adalah seseorang (penjual) menjual sesuatu dan mengambil dari pembeli sejumlah uang dan dinamai 'urbunan untuk memperkokoh hubungan transaksi diantara keduanya dengan asas sesungguhnya pembeli apabila jadi melaksanakan akad maka akan menyempurnakan pembayaran 'urbunnya, dan apabila pembeli membatalkan transaksi tersebut maka 'urbun (uang muka) menjadi milik penjual ('Afanah n.d.).

6. Menurut 'Athiyab ibn Muhammad Salim Urbun adalah Dikatakan ba'i al-'urban atau ba'i al-'urbun, al-'urbun menurut kebudayaan masyarakat ialah: seorang pembeli mendatangi pemilik barang dagangan (penjual), dan ia (pembeli) menginginkan barang dagangan tersebut, akan tetapi pembeli tidak memiliki uang yang cukup untuk membeli barang dagangan tersebut, maka pembeli berkata kepada penjual: "Aku tidak memiliki uang yang lengkap, akan tetapi aku menangguhkan pembayaran sampai hari esok (perumpamaan), sehingga aku datang kepadamu dengan uang yang lengkap, maka penjual berkata: "Aku khawatir kamu pergi dan tidak kembali lagi,dan terkadang akan datang pelanggan yang lain yang menginginkan barang dagangan tersebut dan aku tidak mampu untuk menjualnya, maka dari itu aku mengikatkan perjanjian denganmu, akan tetapi berikanlah uang panjar ('urbun) sebagai jaminan sampai kedatanganmu, maka pembeli berkata, "Ini adalah 'urbun (uang muka), harga barang adalah seratus, ini adalah uang sebesar sepuluh untuk menjadi uang muka, apabila aku datang kepadamu dengan membawa uang yang lengkap maka aku akan mengambil barang dagangan tersebut dan aku akan membayar sisanya dan sisanya itu adalah sebesar sembilan puluh (Salim n.d.).

7. Menurut Fadhilah Syaikh al-Utsaimin Urbun adalah mendahulukan pembayaran ketika terjadi proses transaksi jual beli atau sewa menyewa dan uang yang dibayarkan adalah sebagai uang muka, 
apabila transaksi jadi dilakukan maka uang muka tersebut menjadi bagian dari uang transaksi atau uang sewa, dan apabila transaksi tidak jadi dilanjutkan maka uang muka tersebut menjadi milik pemilik pekarangan (dalam transaksi sewa menyewa) atau milik penjual (dalam transaksi jual beli) (Al-Utsaimin 2006).

8. Menurut organisasi ulama agung kerajaan Saudi Arabia,

Urbun adalah seorang pembeli membeli barang dagangan dan menyerahkan kepada penjual sejumlah uang sebagai uang muka, apabila pembeli mengambil barang dagangan maka pembeli menyempurnakan pembayaran, apabila pembeli tidak jadi melakukan transaksi jual beli maka uang muka tersebut milik penjual (Hulwati 2016).

9. Menurut Abu Umar Yusuf ibn Abdullah ibn al-Bir al-Namroi al-Qurthubi

Urbun adalah seseorang membeli budak atau hamba sahaya atau menyewa binatang ternak kemudian berkata kepada penjual atau pemberi sewa, "Aku berikan kepadamu satu dinar atau satu dirham atau lebih dari itu atau kurang dari itu, apabila aku mengambil barang dagangan tersebut atau aku mengendarai binatang ternak tersebut, maka apa yang aku berikan sebagai uang maka sebagai bagian dari pembayaran atau sebagian dari bagian uang sewa ternak, dan apabila aku meninggalkan barang dagangan dan hewan ternak tersebut maka apa yang aku berikan sebagai uang muka kepadamu, maka itu menjadi milikmu (penjual) (AlQurthubi 2000).

10. Menurut Ibnu Atsir

Urbun adalah Seseorang membeli barang dagangan dan menyerahkan sejumlah uang kepada penjual, apabila pembeli melangsungkan transaksi jual beli maka pembeli akan membayar penuh, dan apabila pembeli tidak jadi melangsungkan jual beli, maka uang muka tersebut menjadi milik penjual dan tidak pembeli tidak meminta uang mukanya kembali (Al-Jaziri 1979).

11. Menurut Al-Manawi,

Urbun adalah Urban dapat dikatakan pula 'urbun, yaitu seorang pembeli menyerahkan sesuatu kepada penjual, maka apabila pembeli suka terhadap transaksi jual beli tersebut maka uang muka yang diserahkan pembeli kepada penjual menjadi bagian dari uang pembayaran, dan apabila pembeli tidak melanjutkan transaksi jual beli tersebut, maka uang muka tersebut adalah hibah dari pembeli kepada penjual (Al-Manawi 1994).

Dari beberapa definisi yang dikemukakan oleh para pakar dengan menggunakan redaksi yang berbeda-beda di atas, dapat disimpulkan bahwasannya yang dimaksud dengan ba'i al'urbun (uang muka) adalah sejumlah uang muka yang dibayarkan pemesan/calon pembeli yang menunjukan bahwa ia bersungguh sungguh atas pesanannya tersebut. Bila kemudian pemesan sepakat atas barang pesanannya, maka terbentuklah transaksi jual beli dan uang muka tersebut merupakan bagian dari harga barang pesanan (asset) yang disepakati. Bila kemudian pemesan menolak untuk membeli asset tersebut, maka uang muka akan hangus dan menjadi milik penjual.

\section{B. Tinjauan Ekonomi Syari'ah Pada Jual} Beli Golok Cara Panjar Di PG. Binangkit Cibeureum Tanjungsiang Subang

Bai' al Urbun yakni seseorang membeli sesuatu dengan membayar sebagian harga kepada pihak penjual. Jika pembeli megurungkannya maka sebagian harga yang telah dibayarkan tersebut berlaku sebagai hibbah (G. A. Mas'adi 2002). 
Menurut kalangan Hanabilah berpendapat. Mereka menyatakan jual-beli semacam ini boleh hukumnya. Sebagaimana di jelaskan dalam kitab Al-Mughni;

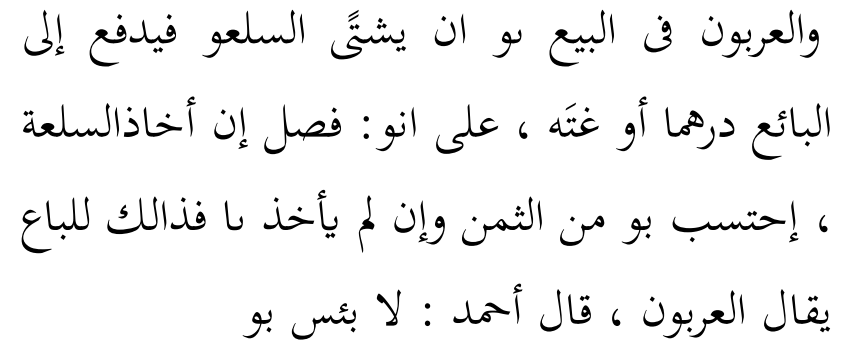

"Jual beli dengan uang panjar adalah untuk membelikan sesuatu dari si penjual, maka harus dibayar kepada penjual satu dirham atau lebih, atas bahwasanya jika mengambil si penjual, menghitung denganya dari pada harga, dan jika tidak mengambilnya bagi pembeli, maka yang demikian di sebutlah jual beli urbun dan berkata Imam Ahmad: membolehkan jual beli sistem 'Urbun'. (Qudamah n.d.).

Pendapat ini juga disandarkan kepada 'Umar ibn Al-Khaththab dan putranya, radhiyallahu 'anhuma. Hanabilah juga mengajukan riwayat yang menunjukkan bolehnya jual-beli ini. 'Abdur Razzaq meriwayatkan dalam Mushannaf-nya dari Zaid ibn Aslam, ia menyatakan:

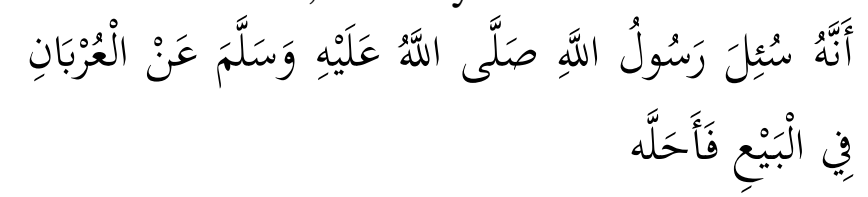

"Rasulullah Saw ditanya tentang jual-beli sistem 'urban, dan beliau membolehkannya."

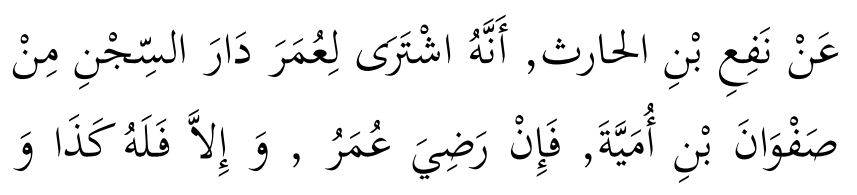

كَذَا

"Dari Nafi bin Al-Harits, sesungguhnya ia pernah membelikan sebuah bangunan penjara untuk Umar dari Shafwan bin
Umayyah, (dengan ketentuan) Apabila Umar suka. Bila tidak, maka Shafwan berhak mendapatkan uang sekian dan sekian"

Penjelasan dari ketiga pendapat tersebut membolehkan secara tegas jual beli panjar di jelaskan dalam kitab pengikut Imam AlHanbali. Muka agar tidak saling menyalahkan jika terjadi pembatalan transaksi jual beli maka harus ada rujukan atau dalil yang bisa digunakan untuk menyikapi penerapan sistem uang muka dalam jual beli golok yaitu menyesuaikan dengan adat kebiasaan yang berlaku di masyarakat, uang muka yang diterapkan bersifat sebagai pengikat kedua pihak untuk saling menghargai akad dalam artian pengelola tidak memberi kesempatan pihak lain yang ingin membeli golok pada obyek yang sama dengan catatan calon pembeli mempunyai niat baik untuk meneruskan akad dan tidak membatalkan transaksi secara sepihak apalagi tanpa mengkonfirmasikan dengan pihak penjual.

Uang muka bersifat sebagai ganti rugi jika calon pembeli tidak jadi membeli golok yang diperjanjikan karena uang mempunyai kesamaan dengan sistem booking (pemesanan).

Tabel 4.1

Ketentuan Panjar

\begin{tabular}{|l|l|c|c|}
\hline \multirow{2}{*}{ No } & Ketentuan Panjar & \multicolumn{2}{|c|}{$\begin{array}{c}\text { Kesesuaian } \\
\text { Syariah }\end{array}$} \\
\cline { 2 - 4 } 1. & $\begin{array}{l}\text { Sesuai } \\
\text { beli, penjual boleh } \\
\text { meminta uang } \\
\text { muka } \\
\text { mencatatnya dan } \\
\text { Sesuai }\end{array}$ \\
\hline & $\begin{array}{l}\text { Besar jumlah uang } \\
\text { muka ditentukan } \\
\text { berdasarkan } \\
\text { kesepakatan }\end{array}$ & $\sqrt{ }$ & \\
\hline
\end{tabular}

EKSISBANK (Ekonomi Syariah dan Bisnis Perbankan), Volume 5, Nomor 1, Juni 2021 http://journal.sties-purwakarta.ac.id/index.php/EKSISBANK/ 


\begin{tabular}{|c|c|c|}
\hline 3. & $\begin{array}{l}\text { Jika kosumen } \\
\text { membatalkan jual } \\
\text { belinya konsumen } \\
\text { harus ganti rugi } \\
\text { kepada penjual } \\
\text { dari uang muka } \\
\text { tersebut }\end{array}$ & $\sqrt{ }$ \\
\hline 4. & $\begin{array}{lr}\text { Jika jumlah uang } \\
\text { muka lebih kecil } \\
\text { dari r kerugian } \\
\text { penjual } \\
\text { meminta } \\
\text { tambahan } \\
\text { pembeli }\end{array}$ & $\sqrt{ }$ \\
\hline 5 & $\begin{array}{l}\text { Jika jumlah uang } \\
\text { muka lebih besar } \\
\text { dari kerugian, } \\
\text { penjual harus } \\
\text { mengembalikan } \\
\text { kelebihannya } \\
\text { kepada pembeli }\end{array}$ & $\sqrt{ }$ \\
\hline
\end{tabular}

Berdasarkan tabel 4.1 di atas bahwa poin pertama menjelaskan bahwa dalam akad jual beli, penjual boleh meminta uang muka kepada pembeli. Maka pernyataan tesebut sudah sesuai dengan fatwa Dewan Syariah Nasional MUI. Begitu juga sebagaimana yang dilakukan oleh Bapak Ada Kosasih pemilik PG. Binangkit jika ada pembeli yang ingin membeli golok dengan cara panjar maka meminta uang muka terlebih dahulu kepada pembeli sebagai jaminan akad jual beli dan uang muka tersebut masuk dalam pembayaran barang tersebut lalu dituliskan dalam buku catatan sebagai bukti tertulis namun pembeli tidak menerima tanda bukti pembayaran seperti kwitansi (Kosasih 2019). Sebagaimana Al-Qur'an Al- Baqarah ayat 282.

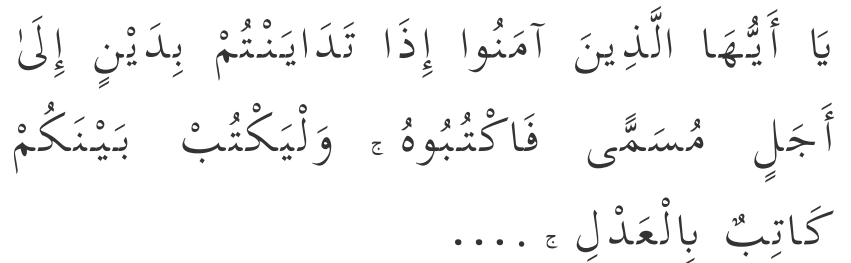

"Hai orang-orang yang beriman, apabila kamu bermu'amalah tidak secara tunai untuk waktu yang ditentukan, hendaklah kamu menuliskannya. dan hendaklah seorang penulis di antara kamu menuliskannya dengan benar."

Lalu pada poin kedua juga sudah berdasarkan Fatwa Dewan Syariah Nasional MUI. Bahwa besar jumlah uang muka ditentukan berdasarkan kesepakatan yang telah ditentukan oleh penjual dan pembeli berapa uang yang harus di bayar terlebih dahulu untuk mengikat barang tersebut. Sama seperti halnya Bapak Ada Kosasih kepada pembeli jika ingin membeli golok dengan cara sistem panjar maka ia bersepakat dulu dengan pembeli berapa uang yang harus di bayarnya stengahnya dulu atau seperempat dulu tergantung kesanggupan pembeli (Kosasih 2019).

Lalu pada poin ketiga Jika kosumen membatalkan jual belinya konsumen harus ganti rugi kepada penjual dari uang muka tersebut. Jika ada konsumen yang membatalkan jual belinya sedangkan barangnya sudah dalam proses kemasan maka konsumen harus mengganti rugi kepada penjual dari uang muka tersebut. Itu juga pernah dialami oleh Bapak Ada Kosasih, dimana kosumen membatalkan pembeliannya padahal barangnya sudah dalam kemasan siap antar lalu Bapak Ada Kosasih meminta ganti rugi dari uang muka tersebut kepada konsumen. Maka ketentuan tersebut sudah sesuai dengan Fatwa Dewan Syariah MUI.

Dan pada poin keempat Jika jumlah uang muka lebih kecil dari kerugian penjual dapat meminta tambahan kepada pembeli. Jika konsumen memesan barang kepada penjual lalu membatalkannya dengan uang muka yang lebih sedikit sedangkan barangnya dalam proses jadi sehingga merugikan penjual lebih dari uang muka tersebut maka penjual dapat 
meminta tambahan ganti rugi kepada pembeli atas pembatalan pembelian tersebut.

Dan pada poin kelima Jika jumlah uang muka lebih besar dari kerugian, penjual harus mengembalikan kelebihannya kepada konsumen. Uang muka dalam pesmesanan barang juga terkadang lebih besar terhadap kerugian barang jika konsumen membatalkan pembelian tersebut maka penjual harus mengembalikan kelebihan dari ganti rugi uang muka tersebut. Hal ini juga pernah di alami Bapak Ada Kosasih dimana konsumen memesan barang dengan uang muka namun memebatalkan pesanannya. Sedangkan uang muka tersebut lebih besar dari keruginan BapakAda Kosasih. Maka Bapak Ada Kosasih mengembalikan kelebihan kerugian dari pembatalan pemesanan tersebut.

\section{KESIMPULAN}

Praktek yang tejadi di PG. Binangkit Cibeureum Tanjungsiang Kabupaten Subang bahwa jual beli golok dengan cara uang panjar akad salam antara penjual golok dan pembeli adalah boleh. Pembeli menyerahkan sejumlah uang kepada penjual, maka uang muka ini sebagai bagian dari harga, pembeli memberikan uang kepada penjual dan mengatakan uang tersebut uang tanda jadi. Kemudian si penjual memberikan jangka waktu dua minggu untuk pembayaran penuh dengan harga tanah yang di sepakati dan juga membuat kesepakatan apabila pembeli membatalkan atau tidak jadi membelinya maka uang panjar/uang muka menjadi milik penjual. Pendapat fikih As-Syafi'i mengenai jual beli uang muka adalah tidak sah berdasarkan, Hadis yang diriwayatkan oleh Amru bin Syuaib yang berbunyi.

"Dari amru bin Syu'aib dari ayahnya dan kakeknya meridhoi Allah akanya bahwa Nabi bersabda: Nabi saw melarang jual-beli 'urban' (HR Abu Daud)'"
Pemahaman fiqh As-Syafi'I ini untuk menghidari dari isi kandungan surah an-Nisa ayat 29. Yang berbunyi.

"Hai orang-orang yang beriman, janganlah kamu saling memakan harta sesamamu dengan jalan yang batil, kecuali dengan jalan perniagaan yang Berlaku dengan suka samasuka di antara kamu. dan janganlah kamu membunuh dirimu Sesungguhnya Allah adalah Maha Penyayang kepadamu"

Sedangkan Pemahaman fikih Hanbali tentang jual beli uang muka berpendapat bahwa jual beli tersebut adalah sah. Berdasarkan Hadis yang diriwayatkan oleh Zaid bin Aslam dan Atsar sahabat atau praktek sahabat Nabi saw, yaitu Umar yang membeli bangunan penjara kepada Safwan bin Ummayyah.

"Rasulullah Saw ditanya tentang jual-beli sistem 'urban, dan beliau membolehkannya."

Pendapat yang berhubungan erat di PG. Binangkit Cibeureum Tanjungsiang antara pendapat fikih As-Syafi'i dan fikih Hanbali tentang pelaksanaan jual beli golok dengan system uang panjar adalah pendapat fikih Hanbali dimana praktek tersebut melakukan jual beli golok dengan memakai uang panjar karena jual beli yang terjadi di PG. Binangkit Cibeureum Tanjungsiang adalah boleh karena hal tersebut untuk memastikan keberlangsungan transaksi dan jaga-jaga atas jaul beli golok.

Berdasarkan tinjauan ekonomi syariah hasil analisis peneliti maka transaksi jual beli golok baik dengan sistem panjar sudah sesuai dengan syariah baik dari ketentuan terkait sighat al-aqd, ketentuan terkait para pihak, ketentuan terkait Mutsman (mabi'), dan ketentuan terkait Tsaman.

\section{DAFTAR PUSTAKA}

'Afanah, Hisan al-Din. Fatawa Yasalunaka. Juz III.

Al-Jaziri, Abu Sa'adat al-Mubarok ibn

EKSISBANK (Ekonomi Syariah dan Bisnis Perbankan), Volume 5, Nomor 1, Juni 2021 
Muhammad. 1979. Al-Nihayah Fi Gharib Wa Al-Atsar. Juz III. Beirut: Dar Kitab al-'Ilmiyyah.

Al-Manawi. 1994. Faidh Al-Qadir. Juz VI. Beirut: Darl Kitab al-'Ilmiyah.

Al-Qurthubi, Abu Umar Yusuf. 2000. AlIstidzkar Al-Jami' Limadzhahib Fuqaha Al-Amshor. Juz VI. Beirut: Darl Kitab al'Ilmiyah.

Al-Ramli, Syamsuddin Muhamad bin Abdul Abbas Ahmad bin Hamzah bin Syihabuddin. Nihayatul Muhtaz Ila Syarhil Minhaz. Juz 3. Bairut: DarulKutub al-Ilmiyah.

Al-Turfawi, Abu Hisan ad-Din. Ba'i Al'Urbun Fi Dho'i Al-Syari'ah AlIslamiyah. tp.

Al-Utsaimin, Muhammad ibn Sholih. 2006. Fatawa Nur 'ala Dirob. Juz II. Muasasah Syaikh Muhammad ibn Sholih alUtsaimin Rohimahullah.

An-Nawawi, Abu zakariya bin Syarof. AlMajmu' Syarh Al-Muhadzab. Bairut: Dar Al-Kutb Al-Ilmiyah.

Arikunto, Suharsimi. 2002. Prosedur Penelitian: Suatu Pendekatan Praktek. Cetakan Ke. Jakarta: PT. Rineka Cipta. Pendekatan Praktek. Revisi IV,. Jakarta: Rineka Cipta.

\section{PT. Asdi Mahasatya.}

As-Syarbaini, Muhamad al-Khatib. 1978. Mugniy Al-Muhtaj. Juz 2. Bairut: Dar alFikr.

Basrun, M. Chairul. 2014. Ilmu Sosial Budaya. Maluku: Universitas Iqra Buru.

Bungin, Burhan. 2001. Metodologi Penelitian Sosial: Format-Format Kuantitatif Dan Kualitatif. Cet. Ke-1. Surabaya:
Airlangga University Press.

Departemen Wakaf dan Persoalan Keiskalam Kuwait. 1427. Muasu'ah Al-Fiqhiyyah AlKuwaitiyyah. Juz IX. Kuwait: Dar Salasil.

Dzajuli. 2007. Kaidah Kaidah Hukum Islam Dalam Menyelesaikan Masalah-Masalah Yang Praktis. Jakarta: Kencana.

Ghazaly, Abdul Rahman, Ghufron Ihsan, and Sapiudin Shidiq. 2010. Fiqh Muamalah. Jakarta: Kencana Prenada Media Group.

Harahap, Herman Tohar. 2017. "Pelaksanaan Jual Beli Kredit Peralatan Rumah Tangga Ditinjau Dari Kompilasi Hukum Ekonomi Syariah (Studi Kasus Di Desa Huristak, Kec. Huristak Kab. Padang Lawas)." IAIN Padangsidimpuan.

Heryanto, Tanto. 2021. "Program Pemeliharaan Karyawan Dalam Mencapai Tujuan Institusi." El-Ecosy: Jurnal Ekonomi dan Keuangan Islam 1(1): https://jurnal.unsur.ac.id/elecosy/article/ view/1139 (February 12, 2021).

Hulwati, Hulwati. 2016. “Aplikasi Bayc A1Murabahah Pada Bank Muamalat Cabang Padang." FITRAH:Jurnal Kajian Ilmu-ilmu Keislaman 1(1): 15. http://jurnal.iain-

padangsidimpuan.ac.id/index.php/F/artic le/view/325.

Jaib, Sa'di Abu. 1988. Al-Qomusal-Fiqhi Lughatan Wa Istilahan. Damaskus: Darul Fikr.

Jamil, Nindi Apridha, Asep Dede Kurnia, and Jalaludin Jalaludin. 2020. "Analisis Mekanisme Praktik Jual Beli Followers Dalam Perspektif Ekonomi Islam Di Media Sosial Instagram." EKSISBANK (Ekonomi Syariah dan Bisnis Perbankan) 4(1): 82-94.

EKSISBANK (Ekonomi Syariah dan Bisnis Perbankan), Volume 5, Nomor 1, Juni 2021 
Kosasih, Ada. 2019. "Jual Beli Golok Dengan Cara Panjar Di PG. Binangkit Kp. Cibeureum Tanjungsiang Subang."

Labib. 2006. Etika Bisnis Dalam Islam. Surabaya: Bintang Pelajar Usaha Jaya.

Mas'adi, A. 2002. Fiqh Muamalah Konstektual. Jakarta: Raja Grafindo Persada.

Mas'adi, Gufron A. 2002. Fiqh Muamalah Kontekstual. Jakarta: Raja Grafindo Persada.

Moleong, Lexy. J. 2000. Metodologi Penelitian Kualitatif. Bandung: Remaja Rosdakarya.

Mulyana. 2009. Ekonomi Syariah Di Serambi Mekah. Aceh: Badan Arsip Perpustakaan.

Musyahidah, Siti, Nia Manora Prasanti, Uswatun Hasanah, and Ferdiawan Ferdiawan. 2020. "Tinjauan Ekonomi Islam Pada Prospek Industri Daur Ulang Sampah Plastik." Jurnal Ilmu Ekonomi dan Bisnis Islam 2(1): 74-89. https://jurnaljiebi.org/index.php/jiebi/arti cle/view/24.

Puspitasari, Ayi, Ahmad Saepudin, and Siti Rohmat. 2019. "Analisis Jual Beli Manggis Sistem Borongan Sekali Musim Panen Dalam Perspektif Ekonomi Syari'ah Di Desa Wanasari Kecamatan Wanayasa Kabupaten Purwakarta." EKSISBANK (Ekonomi Syariah dan Bisnis Perbankan) 3(2): 186-96.

Qudamah, Ahmad bin. Al-Mughni. ed. Juz V. Bairut: Dari Al-Kutb AlIlmiyah.

Rahman, Neni Maulina, S. Sudarno, and Ahmad Roziq. 2018. "Perlakuan Akuntansi Pembiayaan Gadai Dan Cicil Emas PT Bank Syariah Mandiri Jember." e-Journal Ekonomi Bisnis dan Akuntansi $5(1)$ : 53.
JEBAUJ/article/view/7877 (October 28, 2020).

Ramdhani, Rahmat, Rodiyah Rodiyah, and Mardiyansyah Mardiyansyah. 2020. 1 DAWUH : Islamic Communication Journal Brand Image 212 Mart Dalam Meningkatkan Penjualan Produk Perspektif Manajemen Dakwah. https://www.siducat.org/index.php/dawu h/article/view/70 (November 2, 2020).

Rusyd, Ibnu. 2016. Terjemah BidayatulMujahid, Diterjemahkan Oleh Abdurrohman Dan A. Haris Abdulloh, Dari Buku Asli Bidayatul-Mujtahid. Semarang: CV. Asy Syifa.

Salim, Athiyah Ibn Muhammad. Syarah Bulugh Al-Maram. Juz III.

Subarkah, Andi et al. 2012. Himpunan AlQur'an Dan Terjemah New Cordova. Bandung: Syaamil Quran.

Sugiyono. 2006. Metode Penelitian Pendidikan : Pendekatan Kuantitatif Dan Kualitatif Dan R\&D. Bandung: Alfabeta.

Suherman, Rosidi. 2006. Pengantar Teori Ekonomi Pendekatan Pada Teori Ekonomi Mikro Dan Makro. Jakarta: Raja Grafindo Persada.

Utopo. 2002. Metodologi Penelitian Kualitatif. Surakarta: Sebelas Maret University Press.

Zaenuri. 2014. "Konsep Pembiayaan Pemilikan Emas Pada Perbankan Syariah (Studi Di Bank Mandiri Syariah Semarang)." Jurnal at-Taqaddum 6(2).

https://jurnal.unej.ac.id/index.php/e-

EKSISBANK (Ekonomi Syariah dan Bisnis Perbankan), Volume 5, Nomor 1, Juni 2021 http://journal.sties-purwakarta.ac.id/index.php/EKSISBANK/ 